\title{
Total Glucosides of Paeonia lactiflora Pall Suppress Nitric Oxide Production and iNOS Expression in Lipopolysaccharide-Stimulated RAW264.7 Macrophages
}

\author{
Gang Chen ${ }^{1 *}$, Ming-Liang $\mathrm{Tan}^{2}, \mathrm{Xue}^{\mathrm{Gao}}{ }^{2}$ and Shu-Zhen Kong ${ }^{2}$ \\ ${ }^{1}$ School of Environmental and Biological Engineering, ${ }^{2}$ Chongqing Key Laboratory of Nature Medicine Research, Chongqing \\ Technology and Business University, Chongqing 400067, China
}

*For correspondence: Email: gangch_tcm@hotmail.com; Tel: +86-23-6276-8059; Fax: +86-23-6276-9652

Received: 19 December 2013

Revised accepted: 2 June 2014

\begin{abstract}
Purpose: To investigate the effect of total glucosides of Paeonia lactiflora (TGPL) on nitric oxide (NO) production and its potential mechanism in lipopolysaccharide (LPS)-stimulated RAW264.7 macrophage cells.

Methods: RAW264.7 cells were treated with $10-300 \mu \mathrm{g} / \mathrm{ml}$ TGPL and $1 \mu \mathrm{g} / \mathrm{ml} L P S$. Cell survival was determined by MTT assay. NO level was determined by Griess reaction assay. Inducible NO synthase (iNOS) expression and inhibitor-kBa (IKBa) degradation were determined by Western blot assay. DNA binding activity of NF-KB was determined by ELISA assay using Trans AM ${ }^{\mathrm{TM}}$ kit for $p 65$.

Results: The concentrations of TGPL $(10-300 \mu \mathrm{g} / \mathrm{ml})$ used in this study did not affect cell survival of RAW264.7 cells, which suggest that $10-300 \mu \mathrm{g} / \mathrm{ml}$ TGPL did not show cytotoxic effect on RAW264.7 cells. NO level and iNOS protein expression significantly increased in LPS-stimulated RAW264.7 cells compared to the unstimulated cells. However, $10-300 \mu \mathrm{g} / \mathrm{ml}$ TGPL significantly decreased LPSinduced NO level and iNOS protein expression compared to LPS-stimulated RAW264.7 cells alone. Furthermore, 10 - $300 \mu \mathrm{g} / \mathrm{mL}$ TGPL significantly reduced the content of IKBa protein in LPS-stimulated RAW264.7 cells, which suggests that TGPL inhibited LPS-induced degradation of IKBa protein. TGPL remarkably repressed LPS-induced DNA binding activity of P65 in RAW264.7 cells.

Conclusion: These findings suggest that TGP inhibits NO production and iNOS expression through suppression of NF-KB activation in LPS-stimulated RAW264.7 cells.
\end{abstract}

Keywords: Total glucosides, Paeonia lactiflora, Nitric oxide, iNOs, Nuclear factor-kB

Tropical Journal of Pharmaceutical Research is indexed by Science Citation Index (SciSearch), Scopus, International Pharmaceutical Abstract, Chemical Abstracts, Embase, Index Copernicus, EBSCO, African Index Medicus, JournalSeek, Journal Citation Reports/Science Edition, Directory of Open Access Journals (DOAJ), African Journal Online, Bioline International, Open-J-Gate and Pharmacy Abstracts

\section{INTRODUCTION}

Inflammatory mediators, such as tumor necrosis factor- $\alpha \quad($ TNF- $\alpha), \quad$ interleukin-1 $\beta \quad(\mathrm{IL}-1 \beta)$, prostaglandin E2 (PGE2) and nitric oxide (NO), are the prime motivators of inflammation [1]. NO is a short-lived free radical that plays a vital role in diverse physiological processes, including blood vessel tone, neurotransmission, mitochondrial functions, immune regulation and apoptosis. NO is a pro-inflammatory factor in inflammatory condition [2]. NO is synthesized from L-arginine by NO synthases (NOSs): neuronal NOS (nNOS), inducible NOS (iNOS), and endothelial NOS (eNOS). In inflammatory conditions, NO production is catalyzed mainly by iNOS [3]. A significant correlation has been established between NO level and the degree of severity of inflammatory diseases such as rheumatoid arthritis (RA) [4] and systemic lupus erythematosus (SLE) [5] iNOS gene polymorphism has also found to be closely 
associated with susceptibility to RA [6] and SLE [7]. These data stand out that iNOS and NO play crucial roles in the development of inflammation. Nuclear factor (NF)-KB is the key transcriptional factor regulating iNOS gene transcription. NF-KB exists as homo- or hetero-dimeric forms of Rel family proteins such as RelA (p65), RelB, cRel, p50 and p52. NF-KB is present in the cytoplasm in an quiescent state, complexed with the inhibitory $\mathrm{KB}(\mathrm{I} \mathrm{KB})$ proteins including IKBa, IKB , $\mathrm{IKB} \varepsilon, \mathrm{p} 105$ and p100 [8]. Lipopolysaccharide (LPS) [9] or cytokines [10] can trigger NF-KB activation through induced IKB degradation, which resulting in the release and nuclear translocation of p65. In the nucleus, p65 binds to the promoter regions of a number of inflammatory genes including iNOS for transcriptional regulation.

Paeonia lactiflora Pall is a widely used Chinese medicinal plant which is claimed to function in replenishing blood and analgesia. Our previous studies have demonstrated that ShaoyaoGangao-Tang (SGT), a traditional Chinese medicine formula that contains Paeonia lactiflora Pall and Glycyrrhiza uralensis Fisch., can remarkably inhibit the production of inflammatory mediators of adjuvant-induced arthritis [11] or carrageenin-induced pleurisy in rats [12]. However, the effective constituents and potential mechanisms of the anti-inflammatory function of Paeonia lactiflora Pall remain unclear. In this study, we investigated the effect of the total glucosides of Paeonia lactiflora Pall. on NO production, iNOS expression and NF-KB activation in LPS-stimulated RAW264.7 macrophage cells.

\section{EXPERIMENTAL}

\section{Cell culture}

RAW 264.7 macrophage cells were purchased from American Type Culture Collection (ATCC; USA), and subcultured to confluence in Dulbecco's modified Eagle's medium (DMEM; ATCC, USA) containing $10 \%$ fetal bovine serum (Hyclone, USA), $100 \mathrm{U} / \mathrm{ml}$ penicillin (Life Technologies, USA) and $100 \mu \mathrm{g} / \mathrm{ml}$ streptomycin (Life Technologies, USA) in a humidified $5 \%$ $\mathrm{CO}_{2}$ atmosphere at $37^{\circ} \mathrm{C}$.

\section{Nitric oxide determination}

RAW264.7 cells were incubated with 10-300 $\mathrm{\mu g} / \mathrm{ml}$ TGPL (gift from Lansen medicine Co., Ltd, China. TGPL used in this study contained $41.5 \%$ paeoniflorin (w/w) by HPLC analysis) and 1 $\mu \mathrm{g} / \mathrm{ml}$ LPS (Sigma, USA) for $18 \mathrm{~h}$. The nitrite accumulation in the supernatant was assayed by Griess reagent (Sigma, USA). Briefly, equal volume of cell-free culture media $(100 \mu \mathrm{l})$ was reacted with Griess reagent $(100 \mu \mathrm{l})$, and the absorbance at $540 \mathrm{~nm}$ was measured.

\section{MTT assay}

RAW 264.7 cells were incubated with $10-300$ $\mu \mathrm{g} / \mathrm{ml}$ TGPL for $24 \mathrm{~h}$. Then 3-(4,5Dimethylthiazol-2-yl)-2,5-diphenyltetrazolium bromide (MTT; Sigma, USA) was added for $4 \mathrm{~h}$ at the final concentration of $0.5 \mathrm{mg} / \mathrm{ml}$. Subsequently, the culture medium was removed and dimethyl sulfoxide was added to dissolve the formazan crystals, and plates were then read immediately at $570 \mathrm{~nm}$. Wells containing incubation media without cells were used as control. RAW 264.7 cells treated with vehicle only were defined as $100 \%$ viable. Cell survival was defined as the growth of treated cells compared with the untreated.

\section{Western blot}

RAW264.7 cells were incubated with $10-300$ $\mu \mathrm{g} / \mathrm{mL}$ TGPL and $1 \mu \mathrm{g} / \mathrm{mL}$ LPS for $18 \mathrm{~h}$ (for iNOS) or pre-treated with $10-300 \mu \mathrm{g} / \mathrm{mL}$ TGPL for $2 \mathrm{~h}$, and then stimulated with $1 \mu \mathrm{g} / \mathrm{ml}$ LPS for $30 \mathrm{~min}$ (for $1 \mathrm{KB \alpha}$ ). The cellular protein was extracted by lysis buffer $(50 \mathrm{mmol} / \mathrm{L}$ Tris- $\mathrm{Hcl}, \mathrm{pH}$ 8.0, $150 \mathrm{mmol} / \mathrm{L} \mathrm{NaCl}, 1 \% \mathrm{NP}-40,0.1 \%$ SDS, $0.5 \%$ sodium deoxycholate) and EDTA-free protease and phosphatase inhibitor cocktail (Roche, Switzerland). The quantity of proteins was measured using the bicinchoninic acid (Pierce, USA) assay. Equal amounts of protein samples were separated by $10 \%$ sodium dodecyl sulfate polyacrylamide gel electrophoresis, and then transferred onto PVDF membranes (Millipore, USA). After blocking with $5 \%$ non-fat milk for $1 \mathrm{~h}$ at room temperature, the PVDF membranes were incubated with the antiiNOS antibody, anti-IkBa antibody or anti- $\beta$-actin antibody (Santa Cruz, USA) at $4{ }^{\circ} \mathrm{C}$ overnight and subsequently with peroxidase-conjugated second antibody at room temperature for $1 \mathrm{~h}$. The protein bands were detected using $\mathrm{ECL}$ reagents (Millipore, USA). Chemiluminescent signals were detected and analyzed using the ChemiDoc XRS imaging system (Bio-Rad, USA).

\section{Preparation of nuclear protein extracts}

RAW264.7 cells were pre-treated with 10-300 $\mu \mathrm{g} / \mathrm{mL}$ TGPL for $2 \mathrm{~h}$, and then stimulated with 1 $\mu \mathrm{g} / \mathrm{ml}$ LPS for $1 \mathrm{~h}$. Nuclear protein extracts were 
prepared following the manufacturer's instructions (Active Motif, USA). Briefly, cells were gently re-suspended in $500 \mu \mathrm{L}$ hypotonic buffer and incubated for 15 min on ice. After 25 $\mu \mathrm{L}$ of detergent was added and vortexed, the cells were centrifuged for $30 \mathrm{~s}$ at $14000 \mathrm{~g}$ at 4 ${ }^{\circ} \mathrm{C}$. The pellet was used for nuclear fraction collection. Nuclear pellet was resuspended in 50 $\mu \mathrm{L}$ complete lysis buffer, incubated for $30 \mathrm{~min}$ on ice and then centrifuged for $10 \mathrm{~min}$ at $14000 \mathrm{~g}$ at $4{ }^{\circ} \mathrm{C}$. The supernatant (nuclear protein extracts) was collected and stored at $-80{ }^{\circ} \mathrm{C}$.

\section{NF-KB DNA-binding activity}

The binding ability of NF-KB to DNA consensus sequences was measured by ELISA assay using the Trans $A M^{\mathrm{TM}}$ kit for p65 according to the manufacturer's instructions (Active Motif, USA). Briefly, nuclear protein extracts $(5 \mu \mathrm{g})$ were added to the wells, followed by the primary antibody against p65 and the horseradish peroxidase-conjugated secondary antibody. The optical density was measured at $450 \mathrm{~nm}$.

\section{Statistical analysis}

All data are expressed as mean \pm SD. Multiple group comparisons were performed using oneway ANOVA and LSD tests using SPSS 19 software. The differences were considered statistically significant at $p<0.05$.

\section{RESULTS}

\section{Effects of TGPL on NO production and cell survival}

Firstly, we investigated the effect of TGPL on NO production in LPS-stimulated RAW264.7 cells. The level of NO increased significantly from $8.9 \pm$ $1.6 \mu \mathrm{M}$ to $64.7 \pm 11.1 \mu \mathrm{M}$ after LPS-stimulation for $18 \mathrm{~h}(p<0.01$, Fig 1A). 10-300 $\mu \mathrm{g} / \mathrm{ml} \mathrm{TGPL}$ significantly reduced the NO level in a concentration-dependent manner $(p<0.05$ or $p<$ 0.01 , Fig 1A). In particular, at $300 \mu \mathrm{g} / \mathrm{mL}$ TGPL reduced the $\mathrm{NO}$ level to $29.2 \pm 4.1 \mu \mathrm{M}$ compared to that of $64.7 \pm 11.1 \mu \mathrm{M}$ in LPS alone-stimulated RAW264.7 cells, corresponding to about $55 \%$ inhibition $(p<0.01)$. At the same time, $10-300$ $\mu \mathrm{g} / \mathrm{ml}$ TGPL did not affect cell survival of RAW264.7 cells compared to the untreated cells (Fig 1B).

\section{Effect of TGPL on iNOS protein expression}

Since iNOS is the key enzyme that catalyzes NO production in inflammatory condition, we investigated the effect of TGPL on iNOS protein expression in LPS-stimulated RAW264.7 cells. Trace expression of iNOS protein was detectable in untreated RAW264.7 cells. However, expression of iNOS protein was considerably induced upon exposure to $1 \mu \mathrm{g} / \mathrm{ml}$ LPS for $18 \mathrm{~h}$ $(p<0.01$, Fig 2A, B). $10-300 \mu \mathrm{g} / \mathrm{ml}$ TGPL significantly decreased LPS-induced iNOS protein expression in RAW264.7 cells $(p<0.01$, Fig 1A, B).

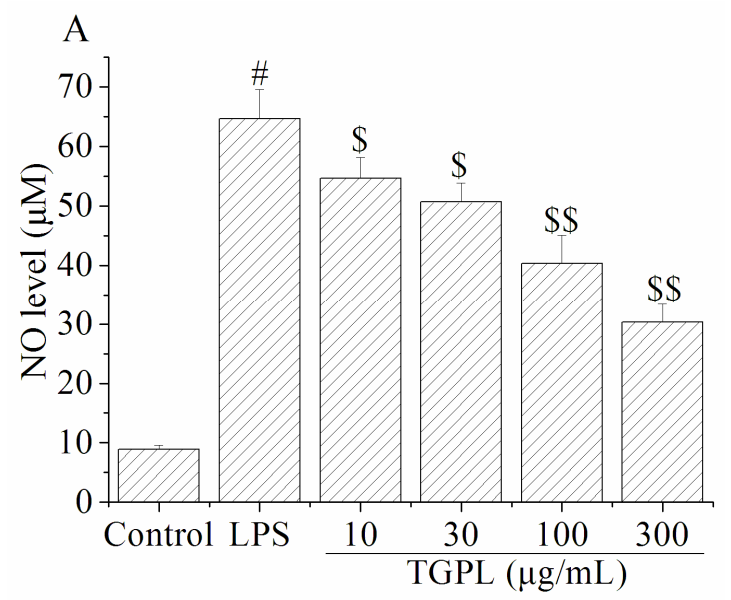

B

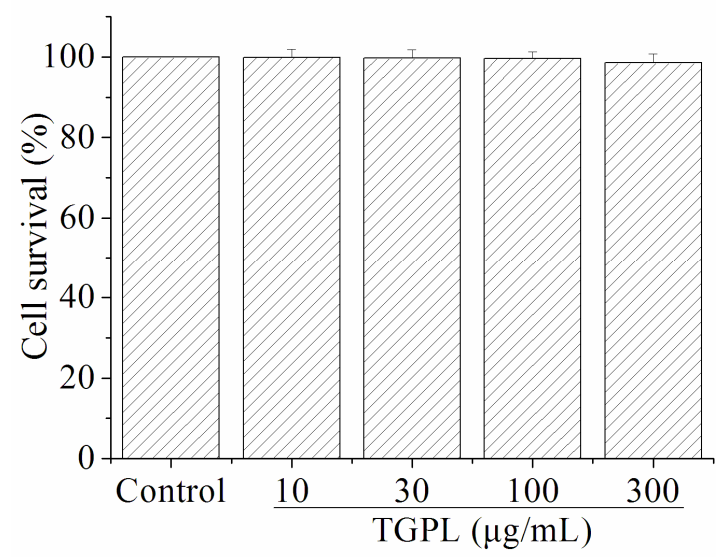

Fig 1: Effects of TGPL on NO production and cell survival in LPS-stimulated RAW264.7 cells. RAW264.7 cells were treated with $10-300 \mu \mathrm{g} / \mathrm{ml} \mathrm{TGP}$ and with or without $1 \mu \mathrm{g} / \mathrm{ml}$ LPS for $18 \mathrm{~h}$ or $24 \mathrm{~h}$. A: Secreted NO in the cell-free culture media was analyzed by Griess reaction assay. B: Cell survival was analyzed by MTT assay. Three independent experiments were performed in duplicate; values are mean \pm SD. ${ }^{\#} p<0.01$ vs. Control group; ${ }^{\$} p<0.05,{ }^{\$ \$}$ $p<0.01$ vs. LPS group

\section{Effect of TGPL on DNA binding activity of NF- KB}

Upon exposure to LPS alone, DNA binding activity of NF-KB was significantly promoted within $1 \mathrm{~h}$ in RAW264.7 cells ( $p<0.01$, Fig 3 ). $10-300 \mu \mathrm{g} / \mathrm{ml}$ TGPL significantly decreased LPSinduced DNA binding activity of NF-KB in a 
concentration-dependent manner in RAW264.7 cells, corresponding to approximately $48 \%$ inhibition at $300 \mu \mathrm{g} / \mathrm{ml} \mathrm{TGPL}(p<0.01$, Fig 3$)$.

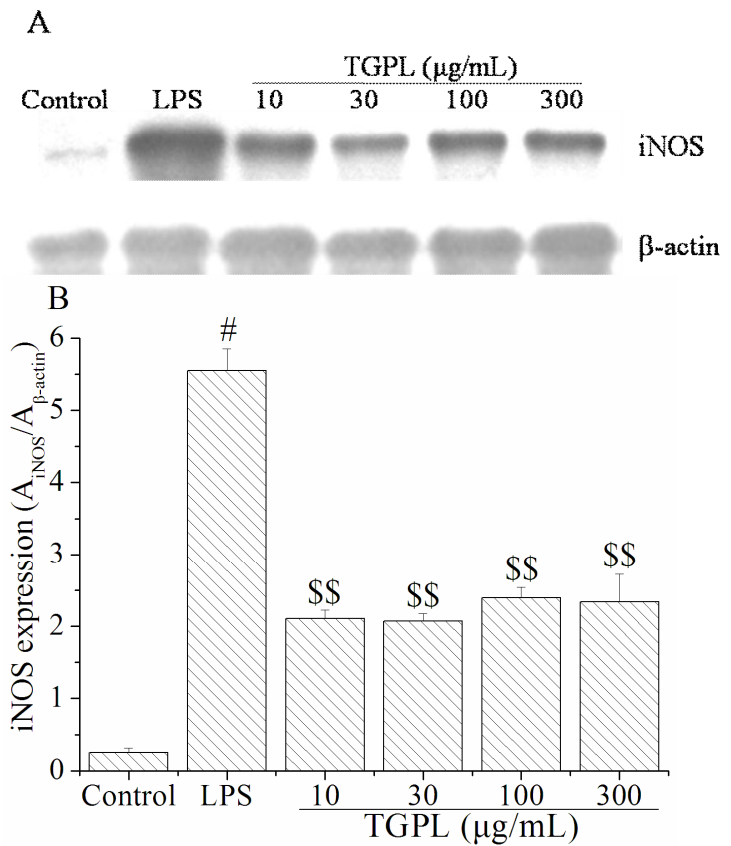

Fig 2: Effect of TGPL on iNOS protein expression in LPS-stimulated RAW264.7 cells. RAW264.7 cells were treated with $10-300 \mu \mathrm{g} / \mathrm{ml} \mathrm{TGPL}$ and with or without $1 \mu \mathrm{g} / \mathrm{ml}$ LPS for $18 \mathrm{~h}$. A: iNOS protein was measured by Western blot assay. B: Bar graphs showed quantitative evaluation of iNOS bands by densitometry. Three independent experiments performed in duplicate; values are mean \pm SD. ${ }^{\#} p<$ 0.01 vs. Control group; ${ }^{\$} p<0.01$ vs. LPS group

\section{Effect of TGPL on IKBa degradation}

Significant reduction of content of IKBa protein occurred within 30 min upon exposure to LPSstimulation alone $(p<0.01$, Fig 4). $10-300 \mu \mathrm{g} / \mathrm{ml}$ TGPL markedly increased content of IKBa protein in LPS-stimulated RAW264.7 cells, especially corresponding to approximately $700 \%$ recovery at $300 \mu \mathrm{g} / \mathrm{ml} \mathrm{TGPL}(p<0.01$, Fig 3$)$.

\section{DISCUSSION}

A number of inflammatory mediators, including TNF- $\alpha, I L-1 \beta$, PGE2 and NO, promote inflammation and aggravate tissue damage [13]. Multiple types of inflammatory cells, including synovial fibroblasts, monocytes/macrophages, osteoclasts, endothelial cells and T-lymphocytes, are regulated by NO [14]. At the same time, cytokines, intercellular adhesion molecules, vascular cell adhesion molecules and matrix metalloproteinases, which accelerate the development of inflammation and tissue damage,

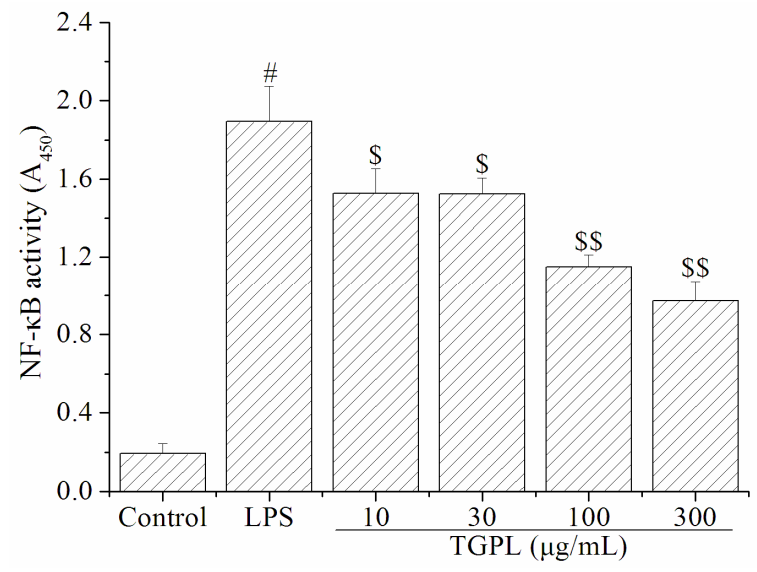

Fig 3: Effect of TGPL on DNA binding activity of NFKB in LPS-stimulated RAW264.7 cells. RAW264.7 cells were pre-treated with 10-300 $\mu \mathrm{g} / \mathrm{ml}$ TGPL for $2 \mathrm{~h}$, and subsequently stimulated with $1 \mu \mathrm{g} / \mathrm{ml}$ LPS for $1 \mathrm{~h}$. Nuclear protein extracts were used to analyze DNAbinding activity of NF-KB by the Trans $\mathrm{AM}^{\mathrm{TM}}$ kit for p65. Three independent experiments performed in duplicate. ${ }^{\#} p<0.01$ vs. Control group. ${ }^{\$} p<0.05,{ }^{\$} p$ $<0.01$ vs. LPS group

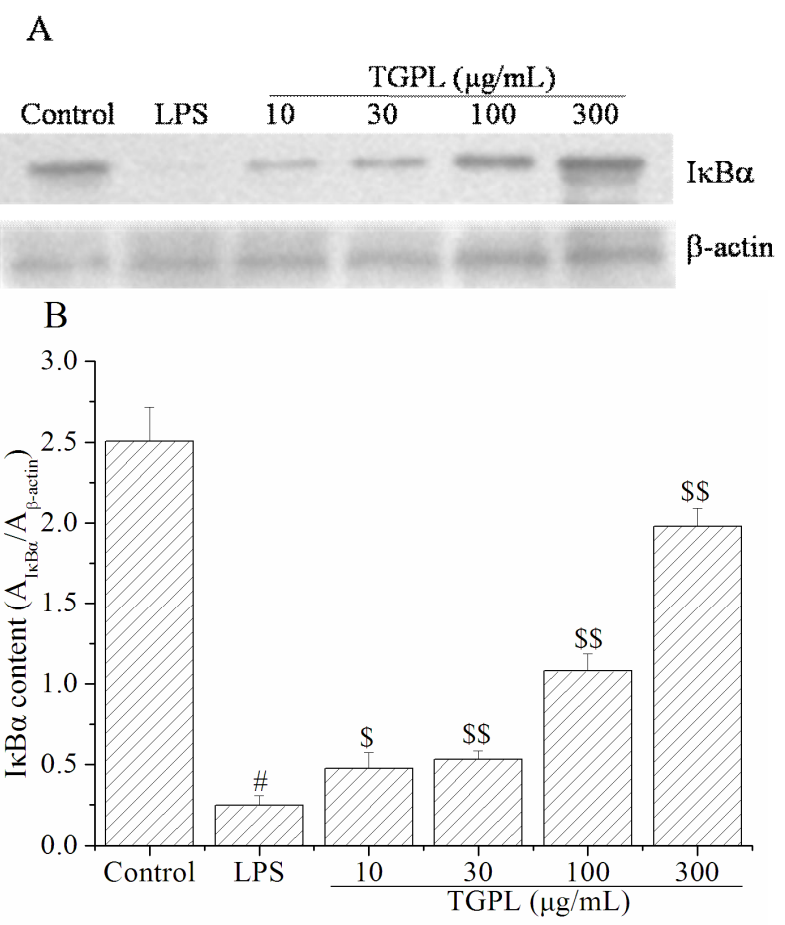

Fig. 4: Effect of TGPL on $1 \kappa B \alpha$ degradation in LPSstimulated RAW264.7 cells. RAW264.7 cells were pretreated with $10-300 \mu \mathrm{g} / \mathrm{ml}$ TGPL for $2 \mathrm{~h}$, and subsequently stimulated with $1 \mu \mathrm{g} / \mathrm{ml}$ LPS for $30 \mathrm{~min}$.

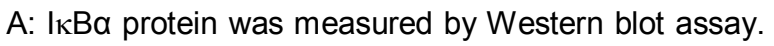
$\mathrm{B}$ : Bar graphs showed quantitative evaluation of $I_{\kappa} B a$ bands by densitometry. Three independent experiments performed in duplicate; values are mean $\pm \mathrm{SD} ;{ }^{\#} p<0.01$ vs. Control group; ${ }^{\$} p<0.05,{ }^{\$ \$} p<$ 0.01 vs. LPS group 
can be induced by $\mathrm{NO}$ in various types of cells [15]. iNOS is the key enzyme for NO production in inflammatory conditions. In spite of the fact that the iNOS pathway is not as rapid as eNOS or nNOS, it is thought to be capable of generating much larger quantities of $\mathrm{NO}$ than constitutive NOS isoforms [16]. These research findings highlight the significance of iNOS and $\mathrm{NO}$ in inflammatory diseases. In this study, we found that LPS considerably induced NO production in murine macrophage RAW264.7 cells. However, TGPL, the active fraction of Paeonia lactiflora Pall. significantly decreased the level of LPS-induced NO in concentrationdependent manner. Due to the fact that all the concentrations of TGPL used in this study did not show cytotoxic effect on RAW264.7 cells, it seems that TGPL decreased NO level, not as a result of reduction in the quantity of cells, but due to some other mechanism of $\mathrm{NO}$ production. Considering that iNOS is the vital enzyme for NO production in inflammatory conditions [3], we investigated the effect of TGPL on LPS-induced NO production in RAW264.7 cells. We found that LPS remarkably induced iNOS protein expression in RAW264.7 cells, and TGPL significantly reduced the LPS-induced iNOS protein expression, which suggests that TGPL was able to regulate the iNOS-NO pathway.

Numerous pro-inflammatory genes, including NO gene, are regulated by a transcriptional factor NF-KB. In the resting state, NF-KB binds to IKB proteins and delays in the cytoplasm [17]. Stimulating factors including LPS and cytokines $[9,10]$ can induce the degradation of IKB proteins, resulting in the nuclear translocation of NF-kB, where NF-kB can promote the transcription of pro-inflammatory genes. In this study, we investigated the effect and mechanism of TGPL on NF-KB activation. LPS significantly increased DNA binding activity of NF-KB in RAW264.7 cells. TGPL notably and concentration-dependently decreased the LPSinduced DNA binding activity of NF-KB in RAW264.7 cells, suggesting that TGPL was able to inhibit the LPS-induced NF-KB activation. Since I $\mathrm{KB} \alpha$ degradation is a prerequisite for the nuclear translocation of NF-KB [17], we investigated the effect of TGPL on IKBa degradation. It was found that LPS reduced the amount of IKBa protein in RAW264.7 cells, suggesting that LPS strongly induced $1 \mathrm{KBa}$ degradation. TGPL restored the reduction of IKBa protein induced by LPS in a concentrationdependent manner. These results indicate that TGPL could suppress NF-KB activation by the way of inhibition of IKBa degradation.
In the theory of traditional Chinese medicine (TCM), Paeonia lactiflora Pall. is thought to possess the outstanding function of "replenishing blood and analgesia". In the clinical practice of TCM, Paeonia lactiflora Pall is frequently applied to treat anemia and a variety of pain in inflammatory diseases. However, the effective constituents and potential mechanisms of the anti-inflammatory function of Paeonia lactiflora Pall. were not totally understood till now. In this study, we demonstrated that TGPL could suppress NO production and iNOS protein expression in LPS-stimulated RAW264.7 cells by the way of inhibition of NF-KB activation.

\section{CONCLUSION}

This study demonstrates that TGPL can significantly inhibit NO production and iNOS protein expression in LPS-stimulated RAW264.7 cells. The mechanism of this action probably entails suppression of $\mathrm{IKB} \alpha$ protein degradation and NF-KB activation in LPS-stimulated RAW264.7 cells. The findings obtained include the effective constituents and potential mechanisms of the anti-inflammatory function of Paeonia lactiflora Pall., and thus constitute new contribution to the research on the antiinflammatory activity of Paeonia lactiflora Pall.

\section{ACKNOWLEDGEMENT}

This work was supported by grants from Innovative Research Team Development Program in University of Chongqing (no. KJTD201020) and Chongqing Educational Ministry (no. KJ060702).

\section{REFERENCES}

1. Astry B, Harberts E, Moudgil KD. A cytokine-centric view of the pathogenesis and treatment of autoimmune arthritis. J Interferon Cytokine Res 2011; 31: 927-940.

2. Nagy G, Clark JM, Buzas El, Gorman CL, Cope AP. Nitric oxide, chronic inflammation and autoimmunity. Immunol Lett 2007; 111: 1-5.

3. Grasemann $H$, Ratjen F. Nitric oxide and L-arginine deficiency in cystic fibrosis. Curr Pharm Des 2012; 18: $726-736$.

4. Onur O, Akinci AS, Akbiyik F, Unsal I. Elevated levels of nitrate in rheumatoid arthritis. Rheumatol Int 2001; 20: 154-158.

5. Oates JC, Shaftman SR, Self SE, Gilkeson GS. Association of serum nitrate and nitrite levels with longitudinal assessments of disease activity and damage in systemic lupus erythematosus and lupus nephritis. Arthritis Rheum 2008; 58: 263-272. 
6. Gonzalez-Gay MA, Llorca J, Sanchez E, Lopez-Nevot MA, Amoli MM, Garcia-Porrua C, Ollier WE, Martin J. Inducible but not endothelial nitric oxide synthase polymorphism is associated with susceptibility to rheumatoid arthritis in northwest Spain. Rheumatology (Oxford) 2004; 43: 1182-1185.

7. Oates JC, Levesque MC, Hobbs MR, Smith EG, Molano $I D$, Page GP, Hill BS, Weinberg JB, Cooper GS, Gilkeson GS. Nitric oxide synthase 2 promoter polymorphisms and systemic lupus erythematosus in African-Americans. J Rheumatol 2003; 30: 60-67.

8. Napetschnig J, Wu H. Molecular basis of NF-kappaB signaling. Annu Rev Biophys 2013; 42: 443-468.

9. Jayasooriya RGPT, Jang YJ, Kang $\mathrm{CH}$, Dilshara MG, Moon DO, Nam TJ, Choi YH, Kim GY. Inhibition of Nitric Oxide and Prostaglandin E2 Expression by Methanol Extract of Polyopes affinis in Lipopolysaccharide-stimulated BV2 Microglial Cells through Suppression of Akt-dependent NF-kB Activity and MAPK Pathway. Tropical Journal of Pharmaceutical Research 2013; 12: 63-70.

10. Ruiz PA, Braune A, Holzlwimmer G, Quintanilla-Fend L, Haller D. Quercetin inhibits TNF-induced NF-kappaB transcription factor recruitment to proinflammatory gene promoters in murine intestinal epithelial cells. $J$ Nutr 2007; 137: 1208-1215.

11. Chen G, Jia P, Gao X. Effect and mechanism of shaoyao-gancao-tang on adjuvant-induced arthritis in rats. African Journal of Pharmacy and Pharmacology 2012; 6: 1611-1616.
12. Chen G, Tan ML, Gao X, Jia P. Dual Regulating Effect of Shaoyao-Gangcao-Tang on COX-2 Expression in Acute and Resolution Phases of CarrageeninInduced Pleurisy in Rats. Tropical Journal of Pharmaceutical Research 2013; 12: 727-733.

13. Montecucco F, Mach F. Common inflammatory mediators orchestrate pathophysiological processes in rheumatoid arthritis and atherosclerosis. Rheumatology (Oxford) 2009; 48: 11-22.

14. Sakaguchi $Y$, Shirahase $H$, Ichikawa A, Kanda M, Nozaki $Y$, Uehara $Y$. Effects of selective iNOS inhibition on type II collagen-induced arthritis in mice. Life Sci 2004; 75: 2257-2267.

15. Jarvinen K, Vuolteenaho $K$, Nieminen R, Moilanen $T$, Knowles RG, Moilanen E. Selective iNOS inhibitor 1400W enhances anti-catabolic IL-10 and reduces destructive MMP-10 in OA cartilage. Survey of the effects of $1400 \mathrm{~W}$ on inflammatory mediators produced by $O A$ cartilage as detected by protein antibody array. Clin Exp Rheumatol 2008; 26: 275282.

16. Nagy G, Clark JM, Buzas E, Gorman CL, Geher P, Perl $A$, Falus $A$, Cope AP. Nitric oxide differentially regulates $T$-cell function in rheumatoid arthritis and systemic lupus erythematosus. Arthritis Research \& Therapy 2007; 9: 26-27.

17. Robinson SM, Mann DA. Role of nuclear factor kappaB in liver health and disease. Clin Sci (Lond) 2010; 118: 691-705. 